DOI: $10.29303 /$ jrpb.v9i1.181

ISSN 2301-8119, e-ISSN 2443-1354

Tersedia online di http://jrpb.unram.ac.id/

\title{
UNJUK KINERJA ALAT PASTEURISASI PADA PROSES PASTEURISASI MADU: STUDI KASUS PT KEMBANG JOYO SRIWIJAYA
}

\author{
Performance of Pasteurization Tools in Honey Pasteurization Process: A Case Study of \\ PT Kembang Joyo Sriwijaya
}

\author{
Sasongko Aji Wibowo ${ }^{1^{*}}$, Anang Lastriyanto ${ }^{1}$, La Choviya Hawa ${ }^{1}$ Erwan $^{2}$, \\ Mochamad Junus $^{3}$, Firman Jaya ${ }^{3}$, Dewi Masyithoh ${ }^{3}$, Jati Batoro' ${ }^{4}$, J.S.A Lamerkabel ${ }^{5}$ \\ ${ }^{1}$ Jurusan Teknik Pertanian, Fakultas Teknologi Pertanian, Universitas Brawijaya, \\ Jalan Veteran No. 1, Malang 65145, Indonesia \\ ${ }^{2}$ Fakultas Peternakan, Universitas Mataram, Jalan Majapahit No 62 Mataram 83125, \\ Indonesia \\ ${ }^{3}$ Fakultas Peternakan, Universitas Brawijaya, Jalan Veteran No. 1, Malang 65145, Indonesia \\ ${ }^{4}$ Fakultas Matematika Ilmu Pengetahuan Alam, Universitas Brawijaya, \\ Jalan Veteran No. 1, Malang 65145, Indonesia \\ ${ }^{5}$ Fakultas Pertanian, Universitas Pattimura, Jalan. Ir. M. Putuhena, Poka, Ambon 97233, \\ Indonesia \\ Email*): Sasongko_aw@student.ub.ac.id \\ Diterima: Desember 2020 \\ Disetujui: Maret 2021
}

\begin{abstract}
One of the post-harvest honey processing processes is the pasteurization process. The pasteurization is the initial stage of honey processing before evaporation. The high demand for honey in Indonesia requires that honey producing companies must use pasteurization tools with large capacities and do not damage the honey content. Honey will be damaged if the pasteurization temperature is more than $70^{\circ} \mathrm{C}$. Besides, the pasteurization process is also still a problem in the honey industry. Therefore, it is necessary to the tools with automatic and fast temperature control in the pasteurization process. The purpose of this study was to observe the rate of heat penetration into pasteurized honey material and the amount of honey weight pasteurized, measured changes in water content, viscosity, degree of brix, and density of density. The results showed that the rate of heat penetration from $35^{\circ} \mathrm{C}$ to $65^{\circ} \mathrm{C}$ in the honey pasteurizer coloni type stoves 1,2 and 3 was 45, 45 and 42 minutes, for a total of $101.22 \mathrm{~kg}$ of honey. Furthermore, it required 50 minutes for traditional tools to heat the honey up to 46,780 kg.. Gas consumption on stove 1 was 0.291 $\mathrm{g} /\left(\mathrm{kg}^{\circ} \mathrm{C}\right)$, stove 2 was $0.281 \mathrm{~g} /\left(\mathrm{kg}^{\circ} \mathrm{C}\right)$, stove 3 was $0.285 \mathrm{~g} /\left(\mathrm{kg}^{\circ} \mathrm{C}\right)$, whereas gas consumption on conventional stove was $0.272 \mathrm{~g} /\left(\mathrm{kg}^{\circ} \mathrm{C}\right)$. The results of water content measurements, viscosity, Brix, and density of density before and after pasteurization were as follows $21.99 \%$, 4.835 poise, $63^{\circ} \mathrm{brix}, 1.356 \mathrm{~kg} / \mathrm{m}^{3}$ and $19.82 \%, 5.453$ poise, $64^{\circ} \mathrm{brix}, 1.358 \mathrm{~kg} / \mathrm{m}^{3}$ respectively.
\end{abstract}

Keywords: honey; pasteurization; penetration; performance 


\begin{abstract}
ABSTRAK
Salah satu proses pengolahan pascapanen madu adalah proses pasteurisasi. Pasteurisasi merupakan tahap awal pengolahan madu sebelum dilakukan evaporasi. Tingginya konsumen madu yang berkualitas di Indonesia mengharuskan perusahaan produsen madu menggunakan alat pasteurisasi dengan kapasitas yang besar. Madu akan mengalami kerusakan apabila suhu pasteurisasi lebih dari $70^{\circ} \mathrm{C}$. Selain itu lama proses pasteurisasi juga masih menjadi masalah dalam industri madu. Oleh sebab itu, perlu dibuat alat pasteurisasi dengan pengontrol suhu otomatis dan cepat dalam proses pasteurisasi. Tujuan dari penelitian ini adalah yang pertama untuk mengamati laju penetrasi panas kedalam bahan madu yang dipasteurisasi, kedua kapasitas alat untuk madu yang dipasteurisasi, ketiga mengetahui perubahan kadar air, viskositas, derajat brix, dan kerapatan masa jenis. Hasil penelitian menunjukan laju penetrasi panas dari suhu $35^{\circ} \mathrm{C}$ hingga $65^{\circ} \mathrm{C}$ pada alat pasteurisasi koloni madu pada kompor 1, 2, dan 3 berturut turut adalah 45, 45, dan 42 menit dengan total madu sebanyak 101,22 kg. Kemudian pada alat konvensional membutuhkan waktu selama 50 menit untuk memanaskan madu sebanyak $46.780 \mathrm{~kg}$. Konsumsi gas pada kompor 1 adalah 0,291 g/( $\left.\mathrm{kg}^{\circ} \mathrm{C}\right)$, kompor 2 adalah $0,281 \mathrm{~g} /\left(\mathrm{kg}^{\circ} \mathrm{C}\right)$, kompor 3 adalah $0,285 \mathrm{~g} /\left(\mathrm{kg}^{\circ} \mathrm{C}\right)$, sedangkan konsumsi gas pada kompor konvensional yaitu $0,272 \mathrm{~g} /\left(\mathrm{kg}^{\circ} \mathrm{C}\right)$. Hasil pengukuran nilai kadar air, viskositas, brix, dan kerapatan massa jenis sebelum dan sesudah dipasteurisasi berturut-turut adalah sebagai berikut $21,99 \%$, 4.835 poise, $63^{\circ}$ brix, $1,356 \mathrm{~kg} / \mathrm{m}^{3}$ dan $19,82 \%, 5,453$ poise, $64^{\circ}$ brix, $1,358 \mathrm{~kg} / \mathrm{m}^{3}$.
\end{abstract}

Kata kunci: madu; pasteurisasi; penetrasi; unjuk kerja

\section{PENDAHULUAN}

\section{Latar Belakang}

Madu merupakan cairan manis yang menyerupai sirup yang dihasilkan oleh lebah madu dan memiliki rasa manis. Rasa manis pada madu berasal dari nektar yang dihisap lebah. Selain itu madu memiliki kandungan utama berupa glukosa dan fruktosa (Abu-Jdayil, et al., 2002). Komposisi madu meliputi 17-20\% kadar air, $80-85 \%$ karbohidrat, dan 0,5-1\% protein, asam amino, vitamin, dan mineral (Baglio, 2018). Madu termasuk produk yang baik untuk kesehatan dan memiliki potensi yang dapat digunakan sebagai produk pangan, farmasi, dan industri kosmetik.

Untuk mendapatkan madu yang berkualitas dan memiliki waktu penyimpanan yang lama, madu harus melalui proses pemanasan yang bertujuan untuk menghambat pertumbuhan organisme dan mengurangi kadar air (DImins, Mikelsone, Kuka, \& Jefremovs, 2014). Pemanasan madu di atas $70^{\circ} \mathrm{C}$ tidak diizinkan karena menyebabkan degradasi senyawa bioaktif yang dapat mempengaruhi kualitas madu (Turhan, et al., 2008). Pemanasan madu dengan suhu lebih dari $70^{\circ} \mathrm{C}$ juga tidak disarankan karena dapat menyebabkan perubahan rasa, warna, dan granulasi madu. Disisi lain dapat mengurangi komponen bioaktif dan antioksidan serta menurunkan kualitas produk madu dan kandungan nutrisinya (Escriche, et al., 2009).

Dalam penelitian (Harjo, et al., 2015) diketahui bahwa madu merupakan bahan makanan dengan kandungan enzim yang tinggi. Enzim merupakan protein yang terdenaturasi oleh beberapa faktor dari luar seperti dalam keadaan ph rendah atau ph terlalu tinggi, kemudian terkena panas atau logam berat (Raeymaekers, 2006). Beberapa jenis enzim yang paling penting dalam kandungan madu adalah diastase, invertase, glukosaoksidase, dan enzim yang aktif dalam fermentasi. White (1978), menyimpulkan bahwa aktivitas enzim diastase (Diastase Number $=\mathrm{DN}$ ) akan menurun seiring penambahan suhu, suhu 
maksimum yang disarankan untuk dilakukanya pasteurisasi adalah $70^{\circ} \mathrm{C}$ karena pada suhu tersebut paruh hidup enzim diatase adalah 5,3jam.

Distribusi suhu pada alat pasteurisasi madu dilakukan pemanasan dengan kompor high press burner. Kemudian akan terjadi penetrasi panas yang melewati tiga lapisan pada alat tersebut: lapisan pertama adalah panci almunium, lapisan kedua berisi air, dan lapisan ketiga adalah panci yang berisi madu. Madu yang berada di dalam wadah lapisan kedua, menerima distribusi panas yang berasal dari panas yang telah melewati ketiga lapisan alat tersebut.

Beberapa perushaan di Indonesia proses pasteurisasi madu dilakukan dengan pemanassampai pada suhu $70^{\circ} \mathrm{C}$ kemudian dilakukan proses pengurangan kadar air dengan evaporasi vakum. Berdasarkan pengamatan yang telah dilakukan dalam proses penyimpanan, beberapa jenis madu yang telah dipanen kemudian di simpan dalam keadan kadar air diatas 22\% akan terjadi pembuihan di bagian permukaan madu (Shelear, 2013). Proses pasteurisasi madu sebelum dilakukan evaporasi selain untuk mengurangi aktivitas fermentasi madu juga mempercepat proses evaporasi penurunan kadar air (Eshete \& Eshete, 2019).

Pada beberapa industri pengolahan madu di Indonesia, proses pasteurisasi madu menggunakan alat pemanas konvensional. Pada alat tersebut, wadah penampung madu berbentuk 1 tabung keatas (vertikal) sehingga mempunyai kekurangan yaitu distribusi suhu selama proses pemanasan menjadi tidak rata antara bahan yang berada di dasar dekat dengan sumber panas (kompor) dan yang berada dibagian bawah permukaan. Suhu madu yang berada dekat dengan sumber panas akan menjadi lebih tinggi jika dibandingkan dengan madu yang berada di permukaan. pengukuran suhu madu dilakukan oleh operator setiap 20 menit sekali menggunakan termometer raksa. Hal tersebut yang membuat suhu tidak terkontrol. Perbedaan tersebut akan mempengaruhi kualitas dan kandungan madu yang dihasilkan. Selain itu terjadi over heat suhu madu lebih dari $70^{\circ} \mathrm{C}$ ketika operator lalai tidak mematikan kompor pada saat suhu sudah mencapai $70^{\circ} \mathrm{C}$.

Salah satu pembuatan alat pasteurisasi yang sedang dikembangkan adalah alat pasteurisasi dengan menggunakan wadah penampung madu dengan ketinggian tabung dalam yang disesuaikan dengan tinggi tabung luar sehingga memungkinkan pendistribusian panas merata. Penggunaan kedua tabung yang lebih presisi pada alat pasteurisasi diharapkan dapat mempengaruhi distribusi dan penetrasi suhu agar menjadi rata dan dapat mempersingkat waktu proses pemanasan. Pengamatan perubahan kadar air, viskositas, derajat brix, serta kerapatan massa jenis madu perlu diketahui untuk melihat perubahannya sebelum madu dipasteurisasi dan setelah dipasteurisasi. Dari permasalahan di atas perlu dilakukan unjuk kerja untuk alat pasteurisasi berkoloni (3 panci double jacket) guna mengetahui tolok ukur perbandingan pendistribusian dan penetrasi suhu kedalam bahan madu.

\section{Tujuan}

Tujuan dari penelitian ini adalah sebagai berikut. Pertama untuk mengamati laju penetrasi panas ke dalam bahan madu yang dipasteurisasi antara alat konvensional dan alat pasteurisasi koloni. Kedua membandingkan kapasitas masingmasing alat. Ketiga dilakukan pengukuran perubahan kadar air, viskositas, derajat brix, dan kerapatan massa jenis pada masing-masing alat.

\section{METODE PENELITIAN}
Alat dan Bahan
Alat
yang
digunakan dalampenelitian ini adalah alat pasteurisasi berkoloni (3 panci double jacket) dilengkapi dengan sistem kontrol yang digunakan untuk mengatur suhu pada saat alat dioperasikan, sensor suhu 
termokopel type-K, moisture analyzer untuk mengukur kadarair, brix refraktometer untuk mengukur brix madu, viskometer untuk mengukur kekentalan, piknometer untuk mengukur kerapatan masa jenis, timbangan digital serta alat tulis. Bahan yang digunakan adalah madu murni dengan jenis madu hitam sebanyak $148 \mathrm{~kg}$ yang diperoleh dari PT Kembang Joyo Sriwijaya Malang dan gas LPG 4 buah. Penelitian dilakukan dilaboratorium Lastrindo Engginering kota Malang dan PT Kembang Joyo Sriwijaya Malang pada bulan Januari sampai Februari 2020.

\section{Metode Pengujian}

Pengujian dilakukan dengan mengamati laju penetrasi panas pada air dan madu murni. Pengujian tahap pertama menggunakan bahan air sebanyak $90 \mathrm{~kg}$ yang dimasukan ke dalam 3 wadah panci dengan kapasitas $200 \mathrm{~kg}$ masing masing seberat $30 \mathrm{~kg}$. Kemudian diukur masing masing suhu awal air sebelum bahan dipanaskan hingga suhu $65^{\circ} \mathrm{C}$. selanjutnya diamati dan dicatat laju penetrasi suhu setiap 5 menit, dan penimbangan berat gas dilakukan diawal dan diakhir waktu selama pemanasan untuk mengetahui konsumsi gas yang digunakan.

Tahap kedua pengujian menggunakan sampel madu sebanyak 148 $\mathrm{kg}$ yang dimasukkan ke dalam masingmasing panci 1, 2 dan 3 sebanyak $33,74 \mathrm{~kg}$ dengan total madu sebanyak 101,22 kg, sedangkan pada alat konvensional digunakan sebagai pembanding percobaan (perlakuan kontrol) dengan sampel yang digunakan sebanyak 46,780 kg. Proses pengujian sama seperti tahap pertama yaitu sampel dipanaskan sampai suhu $65^{\circ} \mathrm{C}$, kemudian dicatat perubahan panas setiap 5 menit. selanjutnya ditimbang susut bobot gas yang digunakan. Pengambilan sampel madu dilakukan sebelum dan sesudah proses pasteurisasi untuk diamati perubahan kandungan mutunya.

Alur pengoprasian alat pasteurisasi koloni adalah sebagai berikut. Pertama dipersiapkan alat pasteurisasi kemudian dihubungkan masing-masing selang dari tabung gas 1,2, dan 3 kedalam input kotak kontrol gas 1,2, dan 3. Kedua selanjutnya dipasangkan juga masing-masing selang output dari kotak kontrol 1,2, dan 3 menuju kompor 1,2 dan 3. Tahap ketiga, madu dituang kedalam 3 buah tabung dibagian dalam dengan setiap tabung terisi sebanyak $33,73 \mathrm{~kg}$. Tahap keempat, air ditambahan kedalam tabung pada lapisan ke dua hingga penuh atau lebih tinggi dari permukaan madu yang akan dipanaskan.Tahap kelima, ditutup setiap tabung bagian dalam karena sensor suhu ditempelkan memanjang pada tutup tabung sehingga letak posisi sensor terdapat dibagian tengah tabung yang sudah terisi madu. Tahap keenam, ditekan tombol power setiap sistem kontrol lalu tekan tombol setting point suhu yang akan digunakan yaitu $65^{\circ} \mathrm{C}$ pada setiap sistem kontrol. Tahap keenam, dihidupkan setiap kompor 1,2, dan 3 pada tekanan api standar atau tidak terlalu besar. Api kompor akan otomatis mengecil apabila suhu yang terbaca pada sensor sudah $65^{\circ} \mathrm{C}$ sehingga suhu akan tetap terjaga $65^{\circ} \mathrm{C}$, apabila suhu turun dibawah $65^{\circ} \mathrm{C}$ api kompor secara otomatis akan membesar.

\section{Parameter Pengamatan \\ a. Laju Penetrasi Panas}

Laju penetrasi panas merupakan penerobosan atau perpindahan panas yang terjadi pada suatu material. Laju penetrasi sangat penting untuk diketahui dalam proses pasteurisasi. Dalam penelitian ini laju penetrasi ditentukan dengan perbandingan kenaikan suhu dengan lama waktu yang dibutukan untuk pindah panas (persamaan 1).

$$
L P=\frac{T}{t}
$$

\footnotetext{
Dimana:

LP $=$ Laju Penetrasi Panas $\left({ }^{\circ} \mathrm{C} /\right.$ menit $)$

$\mathrm{T}=\operatorname{Suhu}\left({ }^{\circ} \mathrm{C}\right)$

$\mathrm{t}=$ Waktu (menit)
} 


\section{b. Konsumsi Gas}

Pengamatan konsumsi gas perlu diketahui untuk mendapatkan jumlah gas yang dibutuhkan untuk memanaskan total bahan yang dipanaskan pada alat pasteurisasi. Pengukuran dilakukan dengan menimbang berat gas awal kemudian dikurangi berat gas akhir, dapat dilihat dalam persamaan 2 .

$\mathrm{KG}=\mathrm{BG}_{1}-\mathrm{BG}_{\mathrm{o}}$

Dimana:

$\mathrm{KG}=$ Konsumsi Gas $(\mathrm{kg})$

$\mathrm{BG}_{1}=$ Berat Gas Awal $(\mathrm{kg})$

$\mathrm{BG}_{\mathrm{o}}=$ Berat Gas Akhir $(\mathrm{kg})$

\section{c. Kadar air}

Kadar air merupakan banyaknya air yang terkandung dalam bahan yang dinyatakan dalam persen. Kadar air juga salah satu karakteristik yang sangat penting pada bahan pangan, karena air dapat mempengaruhi penampakan, tekstur, dan cita rasa pada bahan pangan. Parameter kadar air digunakan untuk mengetahui berapa air yang hilang pada bahan madu yang dipasteurisasi. Pengukuran sampel kadar air menggunakan alat moisture analyzer. Pengukuran kadar air dilakukan pada sampel yang diambil sebelum dan sesudah proses.

\section{d. Viskositas}

Viskositas merupakan ukuran kekentalan fluida yang menyatakan besar kecilnya gesekan dalam fluida. Semakin besar viskositas fluida, maka semakin sulit suatu fluida untuk mengalir dan juga menunjukan semakin sulit suatu benda bergerak di dalam fluida tersebut. Viskositas diukur menggunakan viskometer NDJ-1S untuk mengetahui perubahan kekentalan madu setelah dipasteurisasi. Dari manual book alat ukur viskometer NDJ-1S di tentukan pemilihan spindel nomor 2 dengan kecepatan $12 \mathrm{rpm}$ digunakan untuk mengukur kekentalan madu.

\section{f. Brix}

Derajat Brix (system ${ }^{\circ} \mathrm{Bx}$ ) adalah kadar gula dari larutan berair. Satu derajat Brix adalah 1gram sukrosa dalam 100 gram larutan dan mewakili kekuatan solusi sebagai persentase berat $(\% \mathrm{~b} / \mathrm{b})$. Brix digunakan dalam system makanan untuk mengukur perkiraan jumlah gula (dalam buah-buahan, sayuran, jus, anggur, minuman ringan, dan dalam system manufaktur pati dan gula. Menurut SNI2018 tentang pengukuran kualitas madu, derajat brix diukur menggunakan brix refaktometer dengan skala 60-92 untuk diketahui perbedaan brix sebelum dan sesudah dipasteurisasi.

\section{g. kerapatan masa jenis}

Massa jenis merupakan pengukuran massa persatuan volume. Cara mengukur massa jenis pada umumnya dengan menimbang berat zat cair tersebut dan membaginya dengan volume zat cair yang terukur. Alat yang digunakan untuk mengukur kerapatan jenis madu adalah piknometer $50 \mathrm{ml}$, untuk mengetahui perbedaan nilai kerapatan masa jenis sebelum dan sesudah di pasteurisasi. Persamaan perhitungan kerapat masa jenis menggunakan persamaan 3 .

$$
\rho=\frac{B a-B b}{v} .
$$

Dimana:

$$
\begin{aligned}
\rho= & \text { nilai kerapatan masa jenis }\left(\mathrm{kg} / \mathrm{m}^{3}\right) \\
\mathrm{Ba}= & \text { berat penimbangan piknometer dan } \\
& \text { bahan }(\mathrm{kg}) \\
\mathrm{Bb}= & \text { berat penimbangan piknometer tanpa } \\
& \text { bahan }(\mathrm{kg}) \\
\mathrm{v}= & \text { nilai volume piknometer yang digunakan } \\
& \left(\mathrm{m}^{3}\right)
\end{aligned}
$$$$
\text { HASIL DAN PEMBAHASAN }
$$

Pasteurisasi madu merupakan salah satu proses penting yang harus dilakukan dalam industri produksi madu, karena madu harus mengalami penyimpanan yang lama pada gudang penyimpanan madu. Kualitas madu dapat terganggu ketika 
melalui proses pemanasan karena komponen yang tidak stabil dan termolabil, penguraian vitamin dan kerusakan kandungan enzim terutama ketika dipanaskan lebih dari suhu $70^{\circ} \mathrm{C}$.

Dalam aplikasi pengolahan madu komersial, panas adalah operasi yang penting dan diketahui memiliki potensi untuk menghilangkan mikroorganisme pembusuk, mempermudah pengemasan dan menunda kristalisasi. Umumnya alat pasteurisasi konvensional dengan desain tabung vertikal tinggi mengakibatkan kemampuan laju penetrasi panas tidak stabil yang mengakibatkan kerusakan pada kandungan madu karena panas dapat lebih dari $70^{\circ} \mathrm{C}$ (Gambar 1). Pada alat pasteurisasi konvensional yang ditunjukan pada Gambar 1, terdapat satu pasang tabung vertikal dengan tabung yang dibagian luar sebagai wadah air dan tabung bagian dalam sebagai tempat madu yang dipanaskan. Alat konvensional tersebut dilengkapi dengan satu kompor pemanas tanpa sistem kontrol.

Dalam pengoprasianya, setelah semua alat terpasang dan madu yang akan dipanaskan sudah dimasukan kedalam tabung bagian dalam kemudian dinyalakan kompor. Pengukuran suhu madu dilakukan oleh operator setiap 20 menit sekali menggunakan termometer raksa. Hal tersebut yang membuat suhu tidak terkontrol, kemudian pengukuran suhu hanya dilakukan pada permukaan madu tidak sampai bagian tengah tabung sehingga suhu yang terbaca hanya bagian permukaan madu. Selain itu terjadi over heat suhu madu lebih dari $70^{\circ} \mathrm{C}$ ketika operator lalai tidak mematikan kompor pada saat suhu sudah mencapai $70^{\circ} \mathrm{C}$.

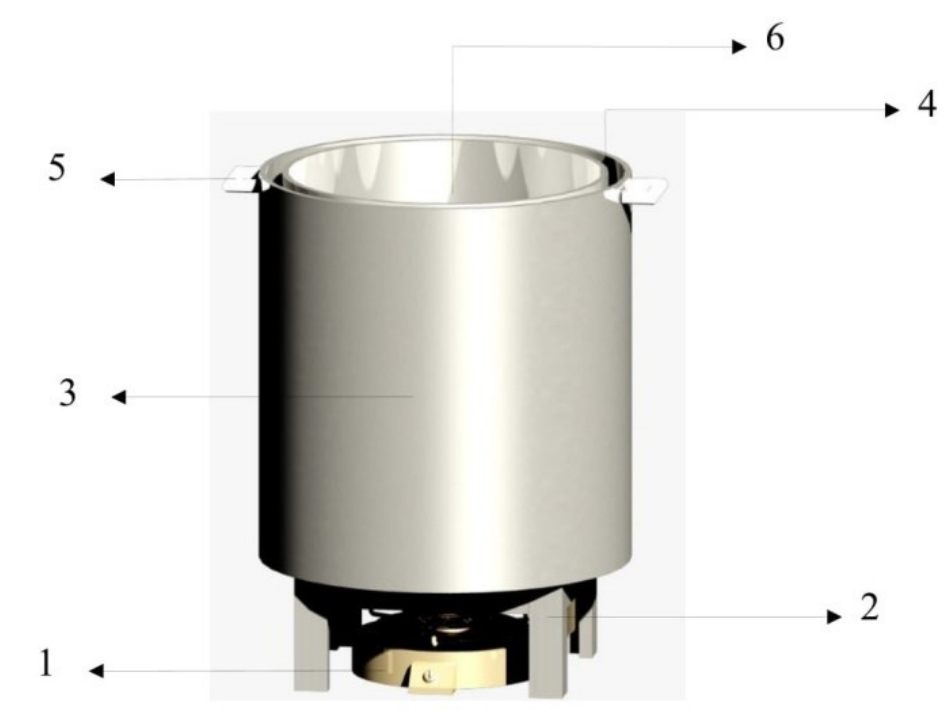

Keterangan : 1. Kompor, 2. Penyangga tabung, 3. Tabung luar, 4. Tabung dalam, 5.Pegangan tabung, 6. Tempat sensor suhu

Gambar 1. Alat Pasteurisasi konvensional

Penggunaan alat pasteurisasi koloni yang dirancang seperti Gambar 2 dengan tinggi tabung dalam yang disesuaikan dengan tinggi tabung luar sehingga pendistribusian panas dapat merata, kemudian alat tersebut dilengkapi dengan kontrol suhu otomatis untuk menjaga suhu madu yang dipanaskan dapat terkontrol secara otomatis. Desain alat pasteurisasi yang dirancang ditunjukan pada Gambar 2, 
model tersebut diharapkan mampu kompor. Nilai laju penetrasi panas dan membuat laju penetrasi panas menyebar kapasitas alat dijelaskan pada sub bab secara merata pada masing-masing berikutnya.

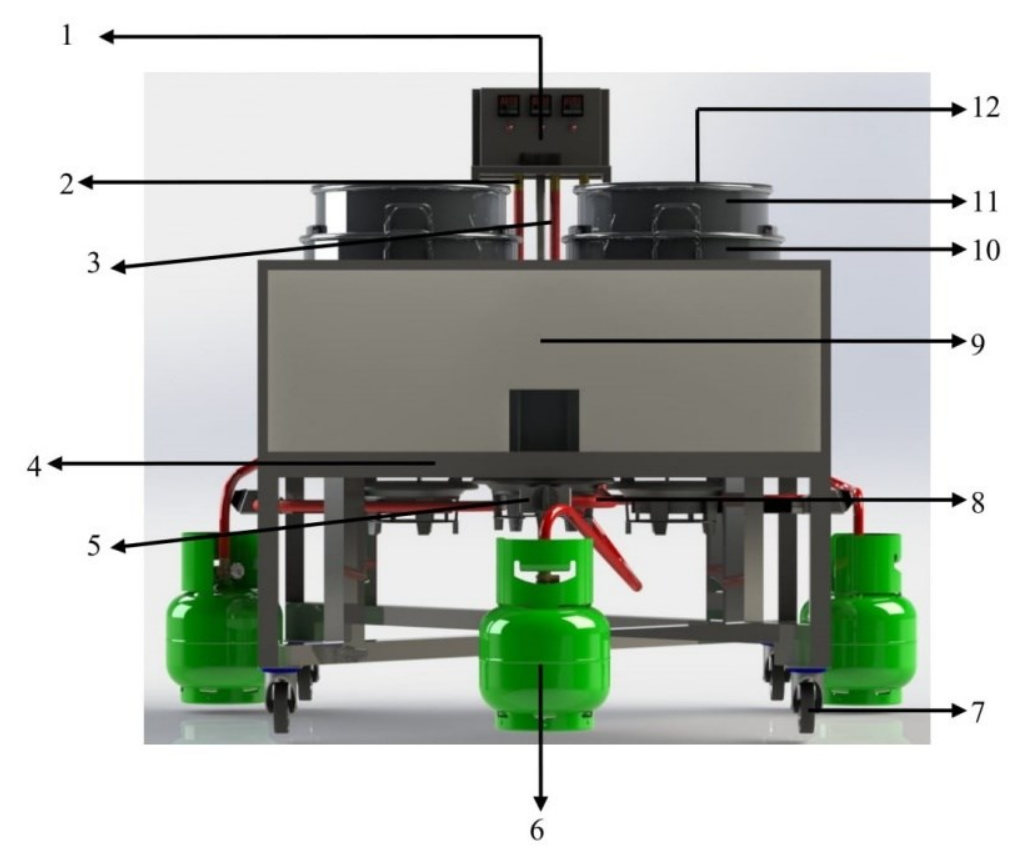

Keterangan: 1. Kontrol panel, 2. Input selang gas ke kontrol panel, 3. Output selang gas ke kompor, 4.Kerangka penopang kompor dan tabung, 5. Kompor high press burner, 6. Tabung gas, 7. Roda kerangka, 8. Instalasi selang gas, 9. Badan penutup panas, 10. Tabung/panci luar, 11.Tabung/panci dalam (wadah madu), 12. Sensor suhu (termokopel teflon)

Gambar 2. Alat Pasteurisasi model koloni

\section{a. Laju Penetrasi Suhu}

Dalam tahap awal penelitian ini, laju pemansan diuji dengan menggunakan bahan air, uji coba tahap awal laju penetrasi panas alat pasteurisasi koloni menggunakan media bahan air dilakukan dilaboratorium Lastrindo Enginering kota malang sebelum dilakukan pengujian dilapangan. Hasil laju penetrasi panas dengan media air diperoleh pada kompor 1, 2 dan 3 ditampilkan dalam bentuk grafik yang ditunjukan pada Gambar 3 .

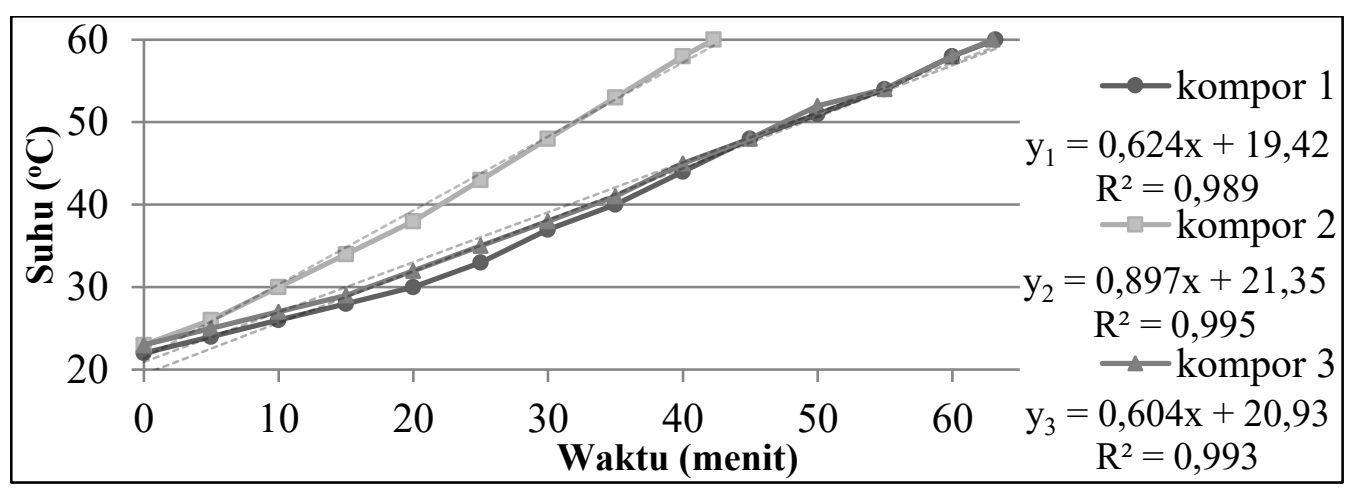

Gambar 3. Grafik laju penetrasi panas

Berdasarkan Gambar 3 hasil penetrasi pada kompor 1 diperoleh waktu selama 63 menit untuk menaikkan suhu air awal $22^{\circ} \mathrm{C}$ sampai dengan suhu akhir $60^{\circ} \mathrm{C}$. Pada 
kompor 2 diperoleh waktu yang lebih singkat yaitu 42 menit untuk menaikkan suhu air awal $23^{\circ} \mathrm{C}$ sampai dengan suhu akhir $60^{\circ} \mathrm{C}$ hal tersebut dikarenakan posisi kompor 2 terdapat dibagian tengah antara kompor 1 dan kompor 3. Sedangkan pada kompor ke 3 diperoleh waktu selama 63 menit untuk menaikan suhu air awal $23^{\circ} \mathrm{C}$ sampai dengan suhu akhir $60^{\circ} \mathrm{C}$.

Tahap selanjutnya pengujian dilakukan menggunakan bahan madu dengan jenis madu hitam sebanyak $148 \mathrm{~kg}$ yang berlokasi di PT Kembang Joyo Sriwijaya malang. Bahan madu sebanyak 101,22 kg dimasukkan kedalam masingmasing tabung alat pasteurisasi koloni panci 1, 2 dan 3 berturut turut sebanyak $33,74 \mathrm{~kg}$. Kemudian madu diukur suhu awal dan suhu akhir proses. Laju penetrasi panas diukur dari suhu awal hingga suhu akhir penetrasi. Sampel madu diambil sebelum dan sesudah pasteurisasi untuk diukur kadar air, viskositas, brix dan perubahan kerapatan masa jenis madu.

Pengujian pada alat pesteurisasi konvensional juga digunakan bahan madu hitam sebanyak 46,780 kg. Madu diukur suhu awal dan suhu akhir pasteurisasi selanjut diamati perubahan suhu laju penetrasi panas. Grafik laju penetrasi panas dengan bahan madu yang diperoleh pada kompor 1, 2, 3 dan konvensional ditampilkan dalam Gambar 4. Berdasarkan Gambar 4, dapat diketahui bahwa nilai laju penetrasi panas alat pasteurisasi koloni dari ketiga kompor lebih besar dibandingkan alat konvensional ditunjukan pada Tabel 1.

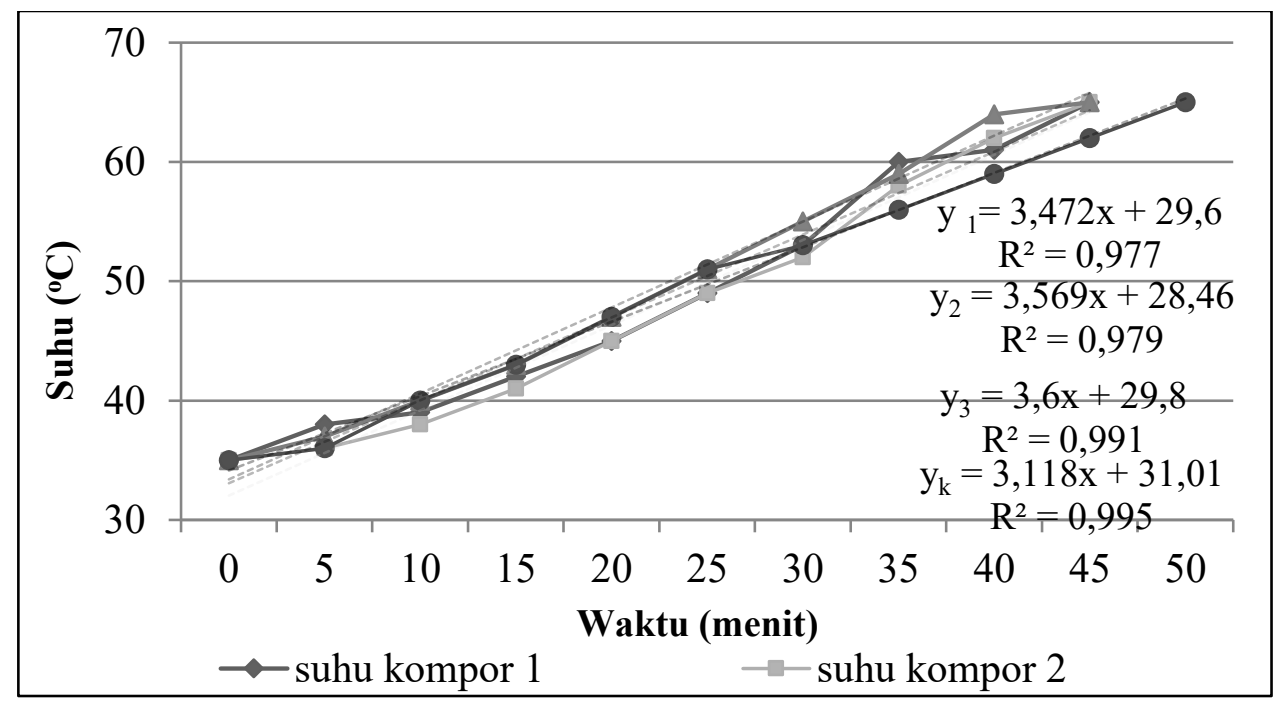

Gambar 4. Grafik laju penetrasi panas kenaikan suhu terhadap lama waktu dengan bahan madu hitam

Tabel 1. Nilai laju penetrasi panas

\begin{tabular}{clc}
\hline No. & Kompor & Nilai $\left({ }^{\circ} \mathrm{C} / \mathrm{Menit}\right)$ \\
\hline 1 & Kompor 1 & 0,6945 \\
2 & Kompor 2 & 0,7139 \\
3 & Kompor 3 & 0,7433 \\
4 & konvensional & 0,6235 \\
\hline
\end{tabular}

Dari grafik laju penetrasi panas pada Gambar 4 dapat dilihat perbedaan lama waktu yang terjadi pada kompor 1,2, dan 3 untuk menaikan suhu awal $35^{\circ} \mathrm{C}$ hingga 
$65^{\circ} \mathrm{C}$ berturut turut adalah 45,45 , dan 42 menit. Kemudian dari table 1 nilai laju penetrasi pada masing-masing kompor 1,2 dan 3 berturut-turut $0,6954{ }^{\circ} \mathrm{C} /$ Menit, $0,7139^{\circ} \mathrm{C} /$ Menit, dan $0,7433{ }^{\circ} \mathrm{C} /$ Menit nilai tersebut lebih besar dibandingkan nilai laju penetrasi konvensional.

Pada alat konvensional membutuhkan waktu selama 50 menit untuk menaikan suhu sampai $65^{\circ} \mathrm{C}$ dengan nilai laju penetrasi panas sebesar $0,6235^{\circ} \mathrm{C} /$ Menit. Kelemahan dari alat konvensional adalah suhu yang terbaca hanya suhu madu yang terdapat pada bagian bawah tabung, ketika sensor suhu diukur pada bagian atas mendekati permukaan bahan madu yang dipanaskan suhu yang terbaca pada sensor masih $45^{\circ} \mathrm{C}$. Penggunaan suhu panas madu di atas $70^{\circ} \mathrm{C}$ tidak dizinkan karena menyebabkan degradasi senyawa bioaktif yang dapat mempengaruhi kualitas madu, sehingga pada kompor konvensional ketika dipanaskan lebih lama untuk menaikan suhu $65^{\circ} \mathrm{C}$ pada bahan yang terdapat di bagian atas tabung akan menyebabkan kenaikan suhu lebih tinggi di bagian dasar pada tabung, sehingga dapat merusak senyawa bioaktif dan bahkan berbentuk karamel(Turhan et al., 2008).

\section{b. Pengukuran konsumsi gas, kadar air, viskositas, brix, dan kerapatan masa jenis sebelum dan sesudah pasteurisasi}

Setelah diketahui konsumsi gas $(\mathrm{kg})$ berdasarkan persamaan (1) selanjutnya di lakukan perhitungan konsumsi gas spesifik dengan mengukur berat gas awal di kurang gas akhir dibagi suhu akhir dikurang suhu awal kemudian dibagi jumlah berat bahan madu yang dipanaskan. Konsumsi gas pada masing masing kompor ditampilkan pada Tabel 2.

Tabel 2. Konsumsi LPG spesifik pada kompor 1,2,3 dan konvensional

\begin{tabular}{clc}
\hline No. & \multicolumn{1}{c}{ Kompor } & Konsumsi LPG g/ $\left(\mathrm{kg}^{\circ} \mathrm{C}\right)$ \\
\hline 1 & Konsumsi gas kompor 1 & 0,291 \\
2 & Konsumsi gas kompor 2 & 0,280 \\
3 & Konsumsi gas kompor 3 & 0,285 \\
4 & Konsumsi gas konvensional & 0,272 \\
\hline
\end{tabular}

Dari perhitungan konsumsi gas spesifik diperoleh hasil konsumsi gas pada masing masing kompor, diketahui konsumsi gas pada kompor 1 adalah 0,291 $\mathrm{g} /\left(\mathrm{kg}^{\circ} \mathrm{C}\right)$, kompor 2 adalah $0,281 \mathrm{~g} /\left(\mathrm{kg}^{\circ} \mathrm{C}\right)$, kompor 3 adalah $0,285 \mathrm{~g} /\left(\mathrm{kg}^{\circ} \mathrm{C}\right)$, ketiga kompor tersebut rata-rata memilik nilai yang hampir sama, sedangkan konsumsi gas pada kompor konvensional yaitu 0,272 $\mathrm{g} /\left(\mathrm{kg}^{\circ} \mathrm{C}\right)$. Dari hasil konsumsi gas pada kompor konvensional dan alat pasteurisasi tidak menunjukan perbedaan yang signifikan, tetapi lama waktu pemanasan berbeda hal tersebut dikarenakan posisi ketiga panci saling berdekatan, sehingga antara satu panci dengan panci yang lainya saling berbagi panas antara satu panci dengan panci yang lainya.

Pada sampel yang diambil sebelum dan setelah proses pasteurisasi dilakukan pengukuran kadar air, viskositas, brix dan kerapatan masa jenis. Hasil pengukuran ditampilkan pada Tabel 3 dan 4.

Tabel 3. Pengukuran kadar air, viskositas, brix dan kerapatan masa jenis pada madu hitam sebelum dan sesudah dipasteurisasi pada alat pasteurisasi koloni

\begin{tabular}{clcc}
\hline No. & \multicolumn{1}{c}{ Pengukuran } & Sebelum pasteurisasi & Sesudah pasteurisasi \\
\hline 1 & Kadar Air (\%) & 21,99 & 19,82 \\
2 & Viskositas (poise) & 4,835 & 5,453 \\
3 & Brix ( ${ }^{\circ}$ brix) & 63 & 64 \\
4 & Kerapatan Massa Jenis $\left(\mathrm{kg} / \mathrm{m}^{3}\right)$ & 1,356 & 1,358 \\
\hline
\end{tabular}


Tabel 4. Pengukuran kadar air, viskositas, brix dan kerapatan masa jenis pada madu hitam sebelum dan sesudah dipasteurisasi pada alat pasteurisasi konvensional

\begin{tabular}{clcc}
\hline No. & \multicolumn{1}{c}{ Pengukuran } & Sebelum pasteurisasi & Sesudah pasteurisasi \\
\hline 1 & Kadar Air (\%) & 21,99 & 20 \\
2 & Viskositas (poise) & 4,835 & 5,424 \\
3 & Brix ( ${ }^{\circ}$ brix) & 63 & 64 \\
4 & Kerapatan Massa Jenis $\left(\mathrm{kg} / \mathrm{m}^{3}\right)$ & 1,356 & 1,342 \\
\hline
\end{tabular}

Dari Tabel 3 dapat diketahui perbedaan nilai kadar air, viskosistas, brix dan kerapatan massa jenis pada madu hitam sebelum dan sesudah dipasteurisasi pada alat pasteurisasi koloni. Perubahan nilai kadar air pada madu sebelum dipasteurisasi adalah $21,99 \%$ dan sesudah di pasteurisasi adalah 19,82\%. Pada kekentalan madu juga mengalami perubahan nilai viskositasnya setelah madu di pasteurisasi yaitu 4,835 poise sebelum dipasteurisasi dan naik menjadi 5,453 poise sesudah dipasteurisasi. Pengukuran viskositas menggunakan viscometer NDJ-1S. selanjutnya pada derajat brix madu juga mengalami kenaikan yaitu dari 63 derajat brix menjadi 64 derajat brix, pengukuran derajat brix menggunakan refraktometer skala $60-90 \%$. Kerapatan masa jenis mengalami sedikit kenaikan yaitu $1,356 \mathrm{~kg} / \mathrm{m}^{3}$ sebelum dipasteurisasi menjadi $1,358 \mathrm{~kg} / \mathrm{m}^{3}$ nilai tersebut hanya mengalami perubahan $0,002 \mathrm{~kg} / \mathrm{m}^{3}$.

Berdasarkan Tabel 4 ditunjukan perbedaan nilai kadar air, viskosistas, brix dan kerapatan massa jenis madu hitam sebelum dan sesudah dipasteurisasi pada alat konvensional. Dapat diketahui perubahan kadar air pada madu sebelum dipasteurisasi adalah $21,99 \%$ dan sesudah di pasteurisasi adalah 20\%. Pada kekentalan madu juga mengalami perubahan nilai viskositasnya yaitu 4,835 poise sebelum dipasteurisasi dan naik menjadi 5,424 poise sesudah dipasteurisasi. Pengukuran viskositas menggunakan viscometer NDJ-1S. selanjutnya pada derajat brix madu mengalami kenaikan yaitu dari 63 obrix menjadi 64 brix, pengukuran derajat brix menggunakan refraktometer skala $60-90 \%$. Kerapatan masa jenis mengalami penurunan yaitu $1,356 \mathrm{~kg} / \mathrm{m}^{3}$ sebelum dipasteurisasi menjadi $1,342 \mathrm{~kg} / \mathrm{m}^{3}$.

\section{KESIMPULAN}

Kesimpulan dari penelitian adalah sebagai berikut. Nilai laju penetrasi panas alat pasteurisasi koloni lebih besar dibandingkan alat konvensional. Kapasitas alat pasteurisasi koloni lebih besar dibandingkan kapasitas alat pasteurisasi konvensional. Nilai perubahan kandungan mutu madu tidak berbeda secara signifikan dari kedua alat.

\section{UCAPAN TERIMA KASIH}

Peneliti mengucapkan terima kasih kepada Lembaga Pengelola Dana Pendidikan (LPDP) yang telah berkontribusi dan mendukung pelaksanaan riset. Kegiatan penelitian ini tidak akan terlaksana tanpa dukungan dan dana dari Lembaga Pengelola Dana Pendidikan (LPDP) selama penelitian.

\section{DAFTAR REFERENSI}

Abu-Jdayil, B., Ghzawi, A. A.-M., AlMalah, K. I. M., \& Zaitoun, S. (2002). Heat Effect on Rheology of Light- and Dark-Colored Honey. Journal of Food Engineering, 51(1), 33-38. https://doi.org/10.1016/S02608774(01)00034-6

Baglio, E. (2018). Chemistry and Technology of Honey Production. In Salvatore Parisi (Ed.), Honey: Pr $^{\circ}$ Cessing Techniques and Treatments (1st ed.). https://doi.org/10.1007/978-3-31965751-6

DImins, F., Mikelsone, V., Kuka, P., \& Jefremovs, A. Ni. (2014). Effect of Different Types of Heat Treatment on 
Invertase Activity in Honey. Foodbalt, 2(1),

$13-18$. https://doi.org/10.13140/2.1.5172.160 5

Escriche, I., Visquert, M., Juan-Borrás, M., \& Fito, P. (2009). Influence of Simulated Industrial Thermal Treatments on The Volatile Fractions of Different Varieties of Honey. Food Chemistry, 112(2), 329-338. https://doi.org/10.1016/j.foodchem.20 08.05.068

Eshete, Y., \& Eshete, T. (2019). A Review on the Effect of $\operatorname{Pr}^{\circ}$ Cessing Temperature and Time duration on Commercial Honey Quality. Madridge Journal of Food Technology, 4(1), 158-162.

https://doi.org/10.18689/mjft-1000124

Harjo, S. S. T., Radiati, L. E., \& Rosyidi, D. (2015). Perbandingan Madu Karet dan Madu Rambutan Berdasarkan Kadar Air, Aktivitas Enzim Diastase dan Hidroximetilfurfural (HMF). Jurnal Ilmu Dan Teknologi Hasil Ternak, 10(1), 18-21. https://doi.org/10.21776/ub.jitek.2015. 010.01 .3

Raeymaekers, B. (2006). A Prospective Biomonitoring Campaign With Honey Bees in a District of Upper-Bavaria (Germany). Environmental Monitoring and Assessment, 116(1), 233-243.

https://doi.org/10.1007/s10661-0067389-8

Saxena, S., Gautam, S., \& Sharma, A. (2010). Physical, $\mathrm{Bi}^{\circ} \mathrm{Chemical}$ and Antioxidant Properties of Some Indian Honeys. Food Chemistry, 118(2), 391-397.

https://doi.org/10.1016/j.foodchem.20 09.05.001

Shelear, H. H. (2013). Effect of Storage and $\operatorname{Pr}^{\circ}$ Cessing Temperatures on Honey Quality. Journal of Babylon:Pure and Applied Sciences,
21(6), 2244-2253. Retrieved from https://www.researchgate.net/publicati on/281865621_Effect_of_Storage_and _Pr ${ }^{\circ}$ Cessing_Temperatures_on_Honey _Quality

Turhan, I., Tetik, N., Karhan, M., Gurel, F., \& Reyhan Tavukcuoglu, H. (2008). Quality of Honeys Influenced By Thermal Treatment. Food Science and Technology, 41(8), 1396-1399. https://doi.org/10.1016/j.lwt.2007.09.0 08

White, J. W. (1978). Honey. Advances in Food Research, 24(C), 287-374. https://doi.org/10.1016/S00652628(08)60160-3 
